\title{
DEVELOPING INSTRUCTIONAL MATERIALS OF ENGLISH MORPHOLOGY FOR ENGLISH DEPARTMENT COLLEGE-LEARNERS
}

\author{
Chothibul Umam \\ STAIN Kediri \\ chothib99@gmail.com
}

\begin{abstract}
The role of knowledge on English Morphology for the students of English Language Education (henceforth ELE) cannot be neglected. However, the preliminary observations done by the researcher during the instructional process of English Morphology at the State College for Islamic Studies (STAIN) Kediri Indonesia, for three academic years shows that most of the students still get difficulty in understanding the course content. The researcher, therefore, is of the opinion that the instructional materials used in the classes need to be developed. The adaptation version of Borg \& Gall (1983) model of R \& D covering preliminary observation, designing preliminary product, expert validation, product revision, field testing or try out, and revision to produce final product is used to develop an instructional material on English Morphology. The products mostly concern on 1) the course content, 2) the exercises, and 3) the level of language difficulty or word choice. The researcher expects that the final product of this study could be used as a handbook for the students in studying English Morphology.
\end{abstract}

Keywords: instructional materials, material development, English morphology

Morphology is a branch of linguistics that studies about the internal structure of words and how they are formed. Although it is a linguistics study, it has a very big role to help ELE department students to acquire the target language. However, ELE students and pure linguistics students have different purposes of learning it. That is why, English Morphology for ELE department students is urgently needed.

The mastery of morphological knowledge plays a very significant role in language learning. English language learners can get many advantages of learning English Morphology. The knowledge of morphology can be applied by the learners to increase their vocabulary, detect the changes of word classes, know the word origins, and enhance their mind to think creatively.
Mastering morphological knowledge will help the students modifying or even changing the class of the word and this means that they could form hundreds or even thousands of derivational words.

In an English department of Islamic College in which the researcher teaches, two credits of English Morphology subject is offered in the fourth semester. It is one of linguistics subject that must be taken by the students beside Phonology, Syntax, Semantics, and Sociolinguistics. This course comprises at least twelve meetings in one semester in which the time allocated for instructional process in each meeting is 100 minutes.

Based on the researcher's observations or preliminary needs analysis, it was found out that many students still faced some difficulties and seemed confused in comprehending the 
course content. In the researcher's opinion, one of the sources of confusion is the books available in the library or learning centre. It does not mean that the books are not qualified, but there are some factors behind this fact. First, the books seemingly do not fit for the students' need. The books are likely not designed for English department students but are for the readers or students whose concern is on pure linguistics. Second, as a result of the first cause, many students got the problem in understanding technical terms and consequently it brings them to a confusion. Third, these books, anyway, do not accomodate the different opinion among linguists, especially morphologists. Fourth, based on the result of the researcher's analysis, most books contain too many topics that are not relevant for ELE department students. Consequently, although the students have copied the book as a learning material, many copied materials are not discussed in the classroom since they do not fit the students' need.

Refering to this fact, it can be stated that students should be equipped with the appropriate materials on English Morphology subject. Teaching/learning material is one of the very crucial elements that has to exist to conduct teaching/earning activities. Indeed, the developed materials should place the students as the actors (students-centered) in instructional processes following Contextual Teaching and Learning (CTL) principles. Moreover, students' needsoriented instructional process nowadays has been the main attention of the education practitioners (Lathief, 2002).

There are sixteen principles that Tomlinson (1998:7-21) summarizes of what he thinks many researchers would agree to be the basic principles of the materials development for the teaching of languages or linguistics. These principles are 1) materials should achieve impact, 2) materials should help learners to feel at ease, 3) materials should help learners to develop confidence, 4) what is being taught should be perceived by learners as relevant and useful, 5) materials should require and facilitate learner selfinvestment, 6) learners must be ready to acquire the points being taught, 7) materials should expose the learners to language in authentic use, 8) the learners attention should be drawn to linguistic features of the input, 9) materials should provide the learners with opportunities to use the target language to achieve communicative purposes, 10) materials should take into account that the positive effects of instruction are usually delayed, 11) materials should take into account that learners differ in learning styles, 12) materials should take into account that learners differ in affective attitudes, 13) materials should permit a silent period at the beginning of instruction, 14) materials should maximize learning potential by encouraging intellectual, aesthetic and emotional involvement which stimulates both right and left brain activities, 15) materials should not rely too much on controlled practice, and 16) materials should provide opportunities for outcome feedback.

In this study, the researcher developed an instructional material on English Morphology designed especially for English department students that fits their need. The instructional material designed covers at least some characteristics and is expected to lead the 
students to be the autonomous learners of the related subject. First, it contained the materials or topics needed by ELE students. Second, it contained some exercises assisting the students in comprehending the course content. And third, it should not use too easy nor too difficult language or word choice, so that the studenst have nothing to do with the level of language difficulty.

The material development in this study is based on constructivist learning theory that learning always builds upon knowledge that a student already knows: a schema. As suggested by Jonassen (1999: 26), the materials are designed to lead the students through questions and activities to discover, discuss, appreciate and verbalize the new knowledge. According to Bain (2004:35), one of the primary goals of using constructivist teaching is that students learn how to learn by giving them the training to take initiative for their own learning experiences.

The product of this research is in the form of a handbook. It comprises three parts. The first part consists of the cover, preface, and table of content. The second part is the main part of the product. It contains course materials that are divided into some units. Each unit is equipped with some exercises related to the topic. And the last part covers bibliography. For the students, the product of the study is expected to be able to increase the students' knowledge on English Morphology. The researcher hopes that the product can help the students in comprehending the course content more easily. For the English teachers, the product can be used to facilitate them in teaching English Morphology.

\section{METHOD}

In line with the purpose of the study, i.e. to develop an instructional material on English Morphology subject for the students of ELE department at STAIN Kediri, then the research design of the study is Research and Development (R\&D). According to Borg a Gall (1983), R\&D cycle consists of ten steps; 1) research and information collection, 2) planning, 3) preliminary form of product, 4) preliminary field-testing, 5) main product-revision, 6) main field-testing, 7) operational product-revision, operational field-testing, 9) final productrevision, and 10) dissemination and implementation. In this study, R\&D design proposed by Borg and Gall (1983) was adapted. The adaptation was done by modifying the steps of the process based on the characteristics of the problem and purpose of this study. The adapted model was preliminary observation, designing preliminary product, expert validation, product revision, field testing or try out, and revision to produce final product.

The first step, preliminary observation, had been done by the researcher during teaching English Morphology for three academic years. The result of the need analysis shows that the role of knowledge on English Morphology for the students of ELE department cannot be neglected. However, the books available in the college library which are intended for native English students are not appropriate for the Indonesian students. The language is also too difficult and the books cover some topics that are unnecessary for Indonesian ELE students. Consequently, most of them faced some difficulties and seemed confused in comprehending the course content. The 
second step is designing a preliminary product, that is an instructional material on English Morphology for the students of ELE department. The researcher designed an English Morphology subject which comprised three parts. The first part consists of the cover, preface, and table of content. The second part is the main part of the product. It contains course materials that are divided into some units. Each unit is equipped with some exercises related to the topic. And the last part covers bibliography. Afterward, the experts of English Morphology were invited to review the product. The experts were two researcher's senior colleagues who had taught English linguistics including Morphology for more than five years. From the experts, the suggestion to revise the first product were obtained. The suggestion covered the lay out of the book, level of language difficulty, types of questions and exercices, misspelled words, as well as topic coverage. The researcher then revised the product based on the experts'suggestions. The revised version of the product is then tried out to some students of ELE department. They were observed and surveyed to examine the appropriateness of the materials. Then the last step is to do a revision and produce the final (revised) product.

The data of this research and development were obtained from two sources; experts and students. The data from the experts were obtained after the material was firstly developed. Meanwhile, the second data were gotten after the students become the respondents in the try-out. The researcher used unstructured interview during needs analysis and two kinds of questionnaire; for the experts and for the students. Unstructured interview were used to collect the data about the students' problems and needs in studying English Morphology. Questionnaire for students (Table 1) was used to get their responses on materials draft during the product tryout. Questionnaire for the experts (Table 2) was used to get the suggestions, comments, and feedback on materials draft. The data from the experts were used as a basis for further product revision.

\section{Table 1. Questionnaire for the Students}

Please give a tick $(\sqrt{ })$ to the appropriate answer according to your evaluation. The score value is (1) for strongly disgree, (2) for disgree, (3) for moderate, (4) for agree, and (5) for strongly agree.

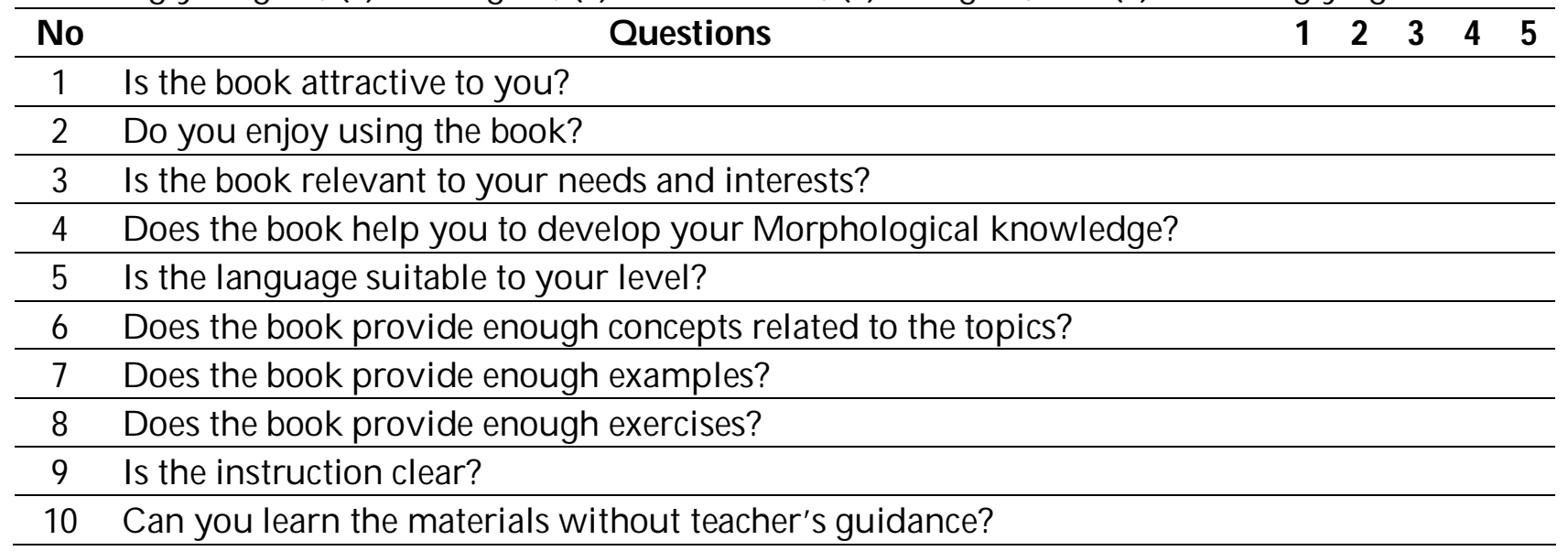


Table 2. Questionnaire for the Expert

Please give a tick $(\sqrt{ })$ to the appropriate answer according to your evaluation. The score value is (1) for strongly disgree, (2) for disgree, (3) for moderate, (4) for agree, and (5) for strongly agree.

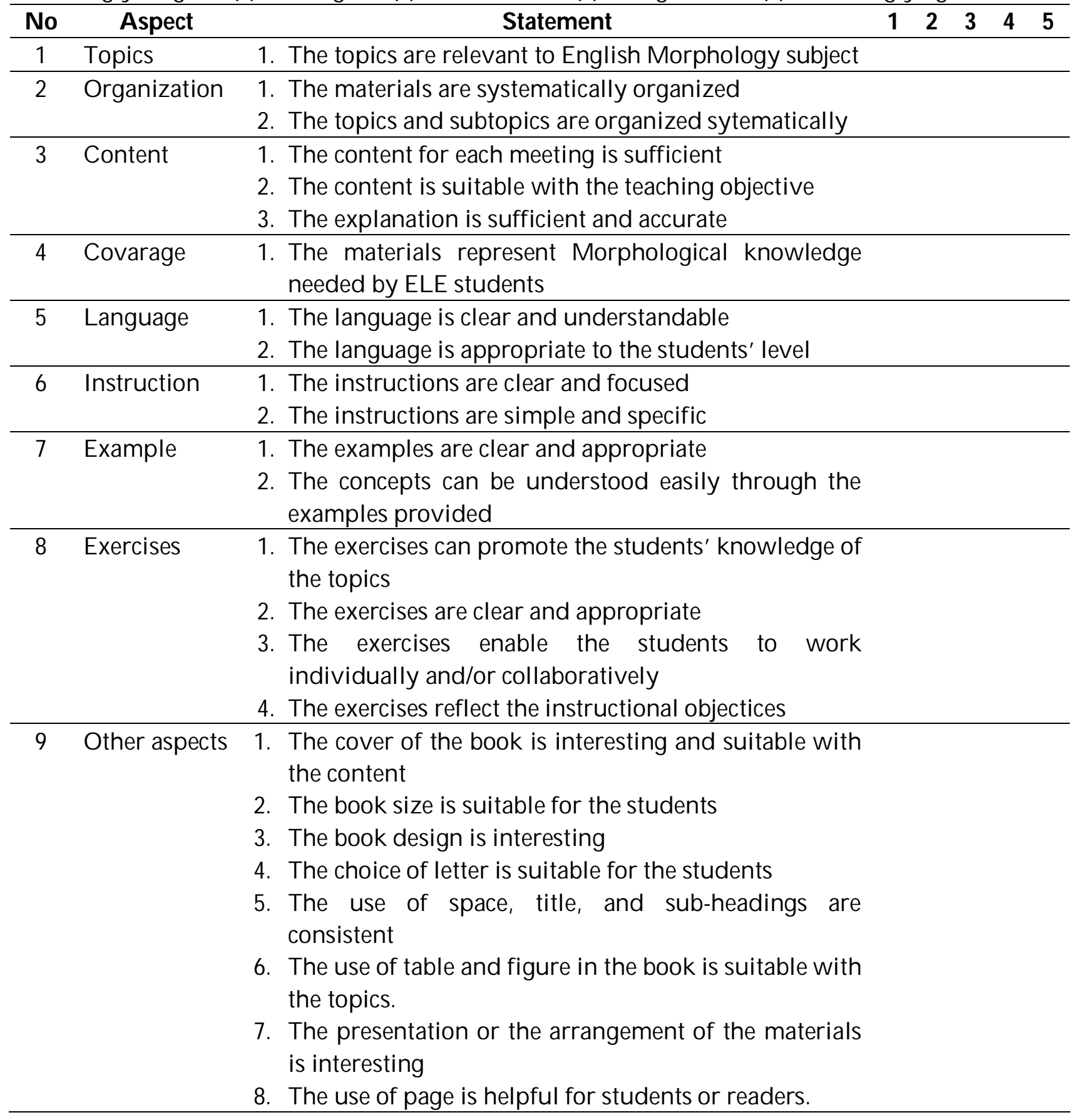

\section{FINDINGS}

The final product of this research is a textbook for the students of English Language Education (ELE) department of STAIN Kediri, Indonesia. It consists of xii and 171 pages in which it comprises three parts. The first part consists of the cover, foreword, and table of content. The second part is the main part of the product. It contains course materials that are divided into five units (i.e,: word and its relatives, morpheme, affix, word formation processes, and compound word for unit one to five respectively). Each unit is equipped with some exercises related to 
the topic. The last part of the book covers bibliography.

The material or the book was developed based on constructivist learning theory that instructional activity builds upon knowledge that a student already knows: a schema. The materials are designed to lead the students through questions and activities to discover, discuss, appreciate, and verbalize the new knowledge. It was designed in order the students learn how to learn by giving them the training to take initiative for their own learning experiences. The topics are presented in a series of theory and tasks requiring the students to sharpen their knowledge, which has about the right level of difficulty for them, so that the language is still within their ability to use.

The expert of English Morphology in this research argued that the products were generally good and eligible to be used as the handbook for ELE department students. However, some suggestions were given to revise some points. Generally the contents, the language, and the steps of delivery in the Handbook were considered good. The use of the tables in some certain topics gave good impression. However, it was suggested that the book should provide diagrams and charts to help the students comprehending the content. Some difficult technical terms should be elaborated as well. The expert also suggested revision on the course overview, especially those related to course identity, course objectives, topics and subtopics, and the scheme of the topics. Furthermore, the experts suggested in order the writer include the related or previous studies to complete the book.
On the basis of the experts' validation and suggestions, the drafts of the materials were revised. Diagrams and charts in some topics, such as in the topic word formation processes, were provided. The research results related to English Morphology were used to support the explanation in the book or the draft.

After the draft was revised based on experts' suggestions, it was then tried out to one class of English Morphology students. The try-out materials were limited to unit three (affixes) and unit four (word formation processes). The try-out was conducted in four sessions in March to April 2014. The researcher acted as the lecturer in conducting the try-out. The implementation of the try-out ran well. The materials were presented without encountering much difficulty. The students seemed motivated in following the try-out. The atmosphere was quite conducive because the students were also eager to follow the try-out. It was conducted to find out more about the usability of the materials, particularly, to get more information on the process of how the teacher and the students could run the learning process using the materials developed. However, during the try-out, as detected from the questionnaire given, some students seemed still getting difficulty in relation to the use of unfamiliar terms in the field of English Morphology. The students suggested that the researcher might provide more elaboration on those terms.

On the basis of the result of the tryout, the final product is then produced. Some difficult terms, like the words lexeme, clitics, transparent, opaque, coinage, suppletion, were elaborated more. Besides, 
the writer provided the footnotes for these difficult terms as well.

\section{DISCUSSION}

The material or the book was developed based on constructivist learning theory that instructional activity builds upon knowledge that a student already knows. The topics were selected based on the priority of students' need, i.e., the needs of students of English language education department especially dealing with English Morphology subject. The materials are designed to lead the students through questions, learning community, and reflection.

Each topic in this developed handbook should be preceded by the lecturers' questions to activate the students' previous knowledge. It is a strategy to prompt, guide, and assess the students' thinking. For the students, it can be used in their inquiry to dig up the information, to confirm the information they have already known and to concentrate on the unknown information. For the lecturers, the students' answers enable them to decide what the class will do to guide the students towards the discussion of the rest of the tasks. The lecturer may encourage the students to share ideas with their friends, to use available dictionaries, reference books, manuals, etc. When the students have already been involved in the discussion process, the questions given to the students are intended to assess how well they are getting along in the learning process.

The materials in this English Morphology handbook should and might also be taught through learning community. It is a technique of learning where a group of students share information in a mutual learning. The implication of this concept is that the result of the learning and teaching process will be achieved by cooperating with each other. The classes are divided into groups so that the students could help each other through group work and make questions and answers about the topics being discussed. They share their understanding about the topics with their friends in their groups.

Reflection before ending each meeting in using this developed handbook is also indispensable part as well. It refers to the evaluation towards the effectiveness of the learning and teaching activities that have already been done. It is intended to determine which parts of the topic to be improved. It can be used to identify the weakness of the instructional process. By identifying such weaknesses, the lecturers can revise the activities, and the students can revise their strategy in doing the activities facilitated by the lecturers in their efforts to construct their morphological knowledge.

\section{CONCLUSION}

The product of this study is a handbook of English Morphology subject designed specifically for Engling Language Education (ELE) department students. For practical purpose, the product had been developed using constructivist learning theory. It was started by gathering information on the needs of the students studying English for education purpose in Indonesian EFL context. Based on this needs analysis, the handbook was then developed.

The developed handbook consists of unit, topic, and sub-topic in which the 
end of every unit is followed by exercises. As the topics are arranged based on the needs and target that should be mastered by the students, there is no grading in the langauge difficulty. It means that one chapter is not more difficult than the language in the other chapters.

Finally, this developed material is not the end of this long process. Teachers, who would like to use this material, are suggested to review it first, or if it is needed, to revise and to make some adaptation depending on the instructional setting. Further researches regarding the effectiveness of the use of this handbook need to be conducted. A pre-experimental research, for example, is needed to

\section{REFERENCES}

Bain, K. (2004). What the Best College Teachers Do. Cambridge: Harvard University Press.

Borg, W.R. \& Gall, M.D. (1983). Educational Research: An Introduction. New York and London: Longman Inc.

Jonassen, D.H. (1999). Contextual Teaching and Learning. Thousand Oaks: Corwin Press, Inc. investigate its effectiveness. Comparing the pretest scores administered before the ELE students are taught using this English Morphology materials and post test scores administered at the end of the semester after the same students are taught using this handbook is absolutely pivotal. Another investigation, e.g., quasiexperimental research, might also be done as the follow-up response of this research, in which the researcher compares the test score of one class taught English Morphology using this handbook and the test score of another class taught the same subject without using this developed handbook.

Lathief, M.A. (2002). Pengembangan Bahan Ajar Contextual Bahasa Inggris SLTP Cawu 2 Untuk 6 Provinsi di Kalimantan dan Sulawesi. Malang: Laporan Penelitian tidak dipublikasikan.

Tomlinson, B. (1998). Materials Development in Language Teaching. Cambridge: Cambridge University Press. 